\title{
PEMBERDAYAAN MASYARAKAT SEKITAR HUTAN PENDIDIKAN UNIVERSITAS HASANUDDIN DESA ROMPEGADING KABUPATEN MAROS MELALUI PENGEMBANGAN MELIPONIKULTUR
}

\author{
Andi Prastiyo1", Sitti Nuraeni², Marwan Rajab ${ }^{3}$, Tumanan4, \\ Isnul Karima Tullah', Nurfadilah Latif6, Nirmala Armidha7, Marshabilla ${ }^{8}$, \\ Khairunnisa Salsabillah ${ }^{9}$, Andi Mustainah Rusli10, Diky Wahyudi11 \\ 1,23,4,5,6,7,8,9,10,11 Universitas Hasanuddin, Makasar, Indonesia \\ *Penulis Koresponsensi, email: andipr34@gmail.com
}

\begin{abstract}
The forest bee farmer group in Rompegading Village still has problems regarding the limitions of hunting for forest bees which are only seasonal, safety and environmental risks and limited knowledge of trigona bee cultivation. With the program offered, the community can start a new business, namely trigona bee cultivation independently. The implementation of this program stars from socializing the introduction and potential of trigona bees, opening/cleaning cultivation/meliponiary areas, making bee houses, making paths to bee houses, planting food/flowers around bee houses, making bee boxes, searching for colonies in nature, installation of meliponiary signage, site fencing and monitoring and evaluation of activities. The activity was carried out for approximately 5 months starting from July to November 2021. The first harvest of $500 \mathrm{ml}$ of trigona honey was sold and became a special satisfaction for member of the partner group. The Trigona Bee Thematic Village Development Program as an Effort for Community Empowerment in Rompegading Village, Maros Regency can be considered to have gone well because all activities carried out are carried out according to the scheduled timeline. It is hoped that from this PHP2D, the community of partner forest farmer groups have skills in trigona bee cultivation by utilizing the potential of the surrounding environment, so this can be the first step for them to start a trigona bee cultivation business so that it is hoped that a thematic village that is independent and caring for the environment will be created.
\end{abstract}

Keywords : Honey, Meliponiary, PHP2D, Rompegading, Trigona

\begin{abstract}
Abstrak. Kelompok tani lebah hutan Desa Rompegading yang masih memiliki permasalahan mengenai keterbatasan perburuan lebah hutan yang hanya bersifat musiman, resiko keselamatan dan lingkungan serta keterbatasan pengetahuan budidaya lebah trigona. Dengan adanya program yang ditawarakan masyarakat dapat memulai usaha baru yaitu budidaya lebah trigona secara mandiri. Pelaksanaan program ini mulai dari sosialisasi pengenalan dan potensi lebah trigona, pembukaan/pembersihan area budidaya/meliponiary, pembuatan rumah lebah, pembuatan jalan setapak menuju rumah lebah, penanaman pakan/bunga-bunga di sekitar rumah lebah, pembuatan kotak lebah, pencarian koloni di alam, pemasangan papan nama meliponiary, pemagaran lokasi dan monitoring serta evaluasi kegiatan. Kegiatan dilakukan kurang lebih selama 5 bulan mulai dari bulan Juli hingga bulan November 2021. Panen perdana madu trigona $500 \mathrm{ml}$ terjual dan menjadi kepuasan tersendiri bagi anggota kelompok mitra. Program Pengembangan Kampung Tematik Lebah Trigona sebagai Upaya Pemberdayaan Masyarakat di Desa Rompegading Kabupaten Maros dapat dinilai sudah berjalan dengan baik pasalnya semua kegiatan yang dilakukan sesuai dengan timeline yang sudah terjadwal. Diharapkan dari PHP2D ini, masyarakat kelompok tani hutan mitra telah memiliki keterampilan dalam budidaya lebah trigona dengan memanfaatkan potensi lingkungan sekitar, maka ini dapat menjadi langkah awal bagi mereka untuk memulai usaha budidaya lebah trigona sehingga diharapkan akan tercipta kampung tematik yang mandiri dan peduli lingkungan.
\end{abstract}

How to Cite: Prastiyo, A., Nuraeni, S., Rajab, M., Tumanan, T., Tullah, I. K., Latif, N., Armidha, N., Marshabilla, Salsabillah, K., Rusli, A.M., \& Wahyudi, D. (2022). Pemberdayaan Masyarakat Sekitar Hutan Pendidikan Universitas Hasanuddin Desa Rompegading Kabupaten Maros melalui Pengembangan Meliponikultur. Mitra Mahajana: Jurnal Pengabdian Masyarakat, 3(1), 41-49. doi: https://doi.org/10.37478/mahajana.v3i1.1525

\section{PENDAHULUAN}

Kelompok tani lebah hutan Desa Rompegading merupakan salah satu wadah atau komunitas pemburu lebah hutan di Kecamatan Cenrana, Kabupaten Maros Sulawesi Selatan. Kelompok ini memiliki anggota dengan latar belakang pendidikan mulai dari SD hingga SLTA. Sebagian besar mereka hanya berprofesi sebagai petani dan pekebun dengan keadaan ekonomi keluarga menengah ke bawah. Dalam kehidupan sehari-hari, masyarakat di desa ini memang 
hanya menggantungkan hidup mereka pada tanaman musiman sehingga mereka belum memiliki penghasilan yang layak.

Berdasarkan hasil wawancara kami dengan salah satu mitra kelompok tani lebah hutan mengatakan bahwa mereka belum bisa memperbaiki pendapatan dengan bertani, berkebun dengan ditambah mencari madu di hutan pada pohon- pohon yang cukup tinggi. Disi lain, resiko memanjat pohon tinggi dapat menyebabkan mereka terjatuh sehingga patah tulang bahkan sampai dengan kematian. Adapun cara yang masih digunakan dalam memperoleh madu masih dengan melakukan pengasapan yang efeknya dapat menimbulkan kebakaran hutan. Sementara itu, Desa ini memiliki topografi perbukitan yang terdapat area pertanian dan juga perkebunan. Selain itu, di sekitar kedua area tersebut teraliri air yang cukup setiap tahunya.

Dari diskusi tersebut, kami mengusulkan kepada mitra untuk melakukan budidaya lebah trigona atau tanpa sengat. Sebagaimana diketahui bahwa dalam kegiatan budidaya lebah trigona sangat membutuhkan pakan yang melimpah dari bunga-bunga tanaman pertanian, perkebunan serta sumber air yang mengalir dan kondisi yang cuaca sangat cocok untuk tempat budidaya (Dewantari \& Suranjaya, 2019). Selain itu, desa ini juga memiliki suhu dan kelembaban udara yang ideal bagi peternak lebah trigona. Kegiatan budidaya lebah trigona juga tidakmembutuhkan lahan yang terlalu luas serta perawatannya mudah dan tidak terlalu mahal (Yuni et al., 2018). Hal ini juga membentuk membuat hubungan simbiosis mutualismne antara lebah yang memanfaatkan sari-sari bunga untuk produksi madu dan tanaman yang dibantu dalam penyerbukan sehingga produksi dapat melimpah.

Di sisi yang lain, produksi madu di dalam negeri masih kurang yaitu sekitar 1.000-1.500 ton per tahun dari kebutuhan nasional sekitar 3.000 ton dan masih harus mengimpor sebesar 70\% (Mursito, 2011). Untuk konsumsi madu di negara negara maju seperti Jerman, Jepang, Inggris, dan Perancis mencapai 700-1500 g/kapita/tahun (Jaramaya, 2018). Ini menunjukkan permintaan madu untuk kebutuhan lokal belum dapat dipenuhi sehingga dapat dijadikan peluang usaha bagi kelompok tani lebah hutan dari hasil panen budidaya lebah trigona.

Dalam proses budidaya lebah trigona diperlukan pengetahuan dan keterampilan dalam memproduksi madu ataupun membudidayakan lebah trigona. Menurut Balai Penelitian dan Pengembangan Teknologi Hasil Hutan Bukan Kayu (2018), dalam usaha budidaya lebah trigona, penyiapan stup dan pemanenan madu merupakan salah satu faktor cukup penting dalam keberhasilan usaha budidaya. Namun sayangnya, bapak-bapak kelompok tani lebah hutan ini belum memiliki pengetahuan dan keterampilan tersebut sehingga kegiatan pengabdian masyarakat ini ditujukan untuk memberikan keterampilan dan kemandirian bagi masyarakat dalam budidaya lebah trigona, yakni dengan memanfaatkan potensi pertanian, perkebuan sebagai sumber pakan dan kondisi air dan cuaca yang mendukung.

Kegiatan ini akan dilaksanakan dalam bentuk penyuluhan dan pelatihan (praktek langsung) sebagai program Pengembangan Kampung Tematik Lebah Trigona sebagai Upaya Pemberdayaan Masyarakat. Dalam program ini, mitra akan dilatih agar dapat menbudidayakan lebah trigona tersebut sampai pemanenan madu, membuat kemasan produk, memasarkan produk secara online dan menbina komunitas agar lebih terstruktur. Dengan demikian, apabila mitra telah memiliki keterampilan dalam budidaya lebah trigona dengan memanfaatkan potensi lingkungan sekitar, maka ini dapat menjadi langkah awal bagi mereka untuk memulai usaha budidaya lebah trigona sehingga diharapkan akan tercipta kampung tematik yang mandiri dan peduli lingkungan.

Menurut Badan Pusat Statistik Kabuapten Maros (2018), Desa Rompegading merupakan salah satu desa yang berada di Kecamatan Cenrana, Kabupaten Maros yang terbagi dalam empat Dusun yaitu Dusun Bululohe, Dusun Moncong Jai, Dusun Pattiro dan Dusun Lanniti Labuaja. Desa Rompegading mempunyai luas wilayah seluas $17.97 \mathrm{Km}^{2}$ dan jumlah penduduk sebanyak 1.700 jiwa. Batas wilayah di sebelah Utara Desa Baji Pamai berbatasan langsung dengan Kabupaten Pangkep, Di sebelah Timur berbatasan dengan Desa Cenrana Baru, sebelah 
Selatan berbatasan dengan Desa Limapoccoe dan di sebelah barat berbatasan dengan Kecamatan Bantimurung.

Kondisi alam Desa Rompegading memiliki ketinggian daerah yang berkisar 0-500 meter di atas permukaan laut (mdpl). Desa Rompegading tergolong masih asri dengan hamparan sawah dan perkebunan sisi rumah warga yang luas dengan suhu berkisar $28^{\circ}-32^{\circ}$ sehingga kondisi ini cocok untuk potensi pembudidayaan lebah trigona. Dalam kegiatan budidaya lebah trigona, suhu lingkungan memegang peranan yang sangat penting untuk produksi dan kenyamanan koloni lebah (Yuni, et al., 2018).

Mitra dalam kegiatan pengabdian masyarakat ini adalah bapak-bapak yang tergabung dalam kelompok tani lebah hutan. Anggota kelompok ini memiliki usia antara 35-45 tahun dengan latar belakang pendidikan mulai dari SD hingga SLTA.Sebagian besar mereka berprofesi sebagai petani dan pekebun dengan keadaan ekonomi keluarga menengah ke bawah. Lokasinya sangat strategis karena melimpahnya sumberdaya alam hayati yang mendukung agribisnis, berupa beragamnya jenis tumbuhan sebagai sumber pakan lebah maupun kondisi lingkungan tropis yang sangat mendukung keberlanjutan dan kehidupan lebah (Moko, 2008). Jarak yang harus ditempuh ke lokasi dari kampus universitas hasanuddin ke desa sasaran berjarak $59 \mathrm{~km}$ dan 5,4 km dari jarak lokasi anggota tim. Permasalahan-permasalahan yang dihadapi adalah sebagai berikut :

1. Kelompok tani lebah hutan belum bisa memperbaiki pendapatan dengan bertani, berkebun dan mencari madu di hutan.

2. Kelompok tani lebah hutan belum bisa mengoptimalkan potensi dari lingkungan sekitarnya.

3. Kelompok tani lebah hutan tidak memiliki keterampilan dalam budidaya lebah trigona.

4. Kurangnya keinginan kelompok tani lebah hutan dalam memulai prospek usaha madu lebah trigona.

Berdasarkan latar belakang masalah yang telah dijelaskan dari gagasan program holistik pembinaan dan pemberdayaan desa (PHP2D) di Desa Rompegading ini adalah sebagai berikut:

1. Bagaimana cara memperkenalkan potensi lebah hutan Trigona sp. yang dapat dibudidayakan sehingga masyarakat dapat melakukan budidaya guna meningkatkan pendapatannya?

2. Bagaimana cara memberdayakan masyarakat yang masih berburu lebah hutan untuk tidak lagi berburu lebah melainkan membudidayakan lebah?

3. Bagaimana cara meningkatkan kapasitas mayarakat di Desa Rompegadingdalam budidaya lebah Trigona sp., dan penanganan pasca panen seperti pengemasan dan pemasaran?

Tujuan dari program holistik pembinaan dan pemberdayaan desa (PHP2D) adalah untuk memperkenalkan potensi lebah hutan Trigona sp. yang dapat dibudidayakan, memberdayakan petani lebah hutan untuk meningkatkan perekonomian masyarakat Desa Rompegading, Kabupaten Maros dengan cara membentuk kelompok tani budidaya lebah Trigona sp. yang berkualitas dan berkelanjutan dan meningkatkan kapasitas kelompok tani budidaya lebah Trigona sp. di Desa Rompegading dalam budidaya lebah Trigona sp., dan penanganan pasca panen seperti pengemasan dan pemasaran.

\section{METODE PELAKSANAAN}

Kegiatan pengabdian masyarakat ini akan dilaksanakan dalam bentuk kegiatan pelatihan dan pendampingan yang diwujudkan dalam sebuah program yang diberi nama Program Pengembangan Kampung Tematik Lebah Trigona sebagai Upaya Pemberdayaan Masyarakat. Pelaksanaan kegiatan dilakukan dengan konsep blended, yaitu luring dan daring. Meskipun demikian, hampir seluruh kegiatan akan dilakukan secara luring. Ada empat kegiatan utama 
dalam program ini, yaitu (1) sosialisasi awal; (2) Penyuluhan dan Pelatihan (3) Pendampingan dan evaluasi.

Sebelum pelaksanaan kegiatan pengabdian terlebih dahulu dilakukan observasi awal ke desa sasaran, selanjutnya tim bersama dosen pendamping akan mengidentifikasi masalah dan mendiskusikan konsep detail mengenai program sebagai dasar penyusunan buku program dan pelaksanaan program ini, termasuk persiapan alat dan bahan. Kegiatan diskusi ini dilakukan secara daring dengan menggunakan media Zoom Meeting.

Selanjutnya, tim akan berkoordinasi dengan ketua kelompok tani lebah hutan sebagai perwakilan mitra untuk membahas mengenai rencana tim melaksanakan kegiatan di tempat mitra. Untuk koordinasi tahap awal akan dilakukan melalui aplikasi Whatsapp dan dilanjutkan dengan komunikasi secara luring dengan tetap menerapkan protokol kesehatan. Program pengabdian ini akan lebih banyak dilakukan secara luring sebagaimana disebutkan sebelumnya. Hal ini disebabkan karena mitra terkendala jaringan internet yang masih sulit diakses. Sementara itu, jumlah peserta bapak-bapak yang akan berpartisipasi dalam Program ini adalah sebanyak 10 orang di mana kesehariannya bekerja sebagai petani dan pekebun.

Pencapaian keberhasilan program ini meliputi, perubahan perilaku masyarakat dengan adanya ketertarikan akan budidaya lebah hutan Trigona sp., terjadinya perubahan fisik dengan mengurangi kegiatan berburu lebah hutan, terjalinnya kerjasama yang baik antara mitra, terbentuknya kelembagaan atau kelompok petani lebah trigona, terjadinya peningkatan kegiatan dan komunikasi, adanya rancangan program tindak lanjut pasca PHP2D dan adanya implementasi mata kuliah di desa dalam proses budidaya lebah trigona ini.

\section{HASIL DAN PEMBAHASAN}

Program Pemberdayaan Masyarakat Sekitar Hutan Pendidikan Universitas Hasanuddin Desa Rompegading Kabupaten Maros Melalui Pengembangan Meliponikultur dapat dinilai sudah berjalan dengan baik pasalnya semua kegiatan yang dilakukan sesuai dengan timeline yang sudah terjadwal. Terkait beberapa program dari Fakultas Kehutanan yang bekerjasama dengan Pemerintah Kabupaten Maros yang khusunya berlokasi di Hutan Pendidikan Universitas Hasanuddin, dimana Hutan Pendidikan itu sendiri memiliki banyak potensi yang dapat dimanfaatkan dan dikembangkan seperti pembangunan arboretum, pembangunan lebah madu dan potensi lainnya (Limonu, 2021). Maka dari itu, tim PHP2D Fakultas Kehutanan Universitas Hasanuddin melakukan pengabdian masyarakat untuk mendukung potensi tersebut dalam budidaya lebah Trigona di Desa Rompegading Kabupaten Maros.

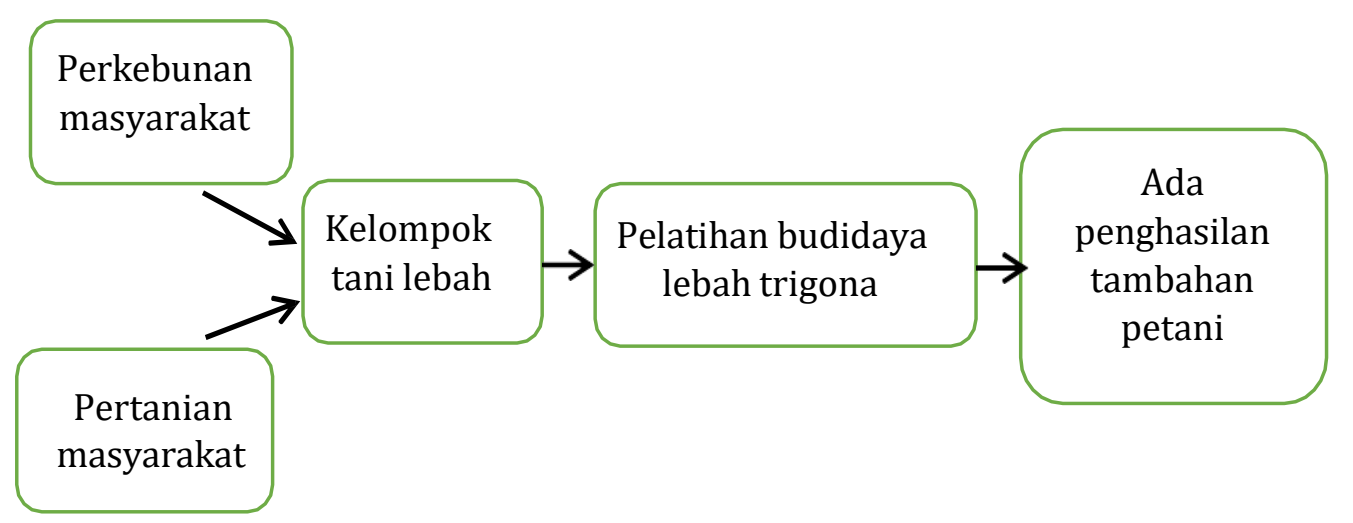

Gambar 1. Kerangka pemetaan potensi, masalah dan partisipasi masyarakat

Menurut Syaifudin \& Normagiat (2020), masyarakat akhir-akhir ini sudah mulai tertarik untuk usaha budidaya, salah satunya adalah budidaya madu Kelanceng atau Kelulut (Trigona sp.). Langkah pertama dalam program ini adalah survei lokasi awal yang tujuannya adalah mengetahui permasalahan dan potensi yang ada di desa tersebut. Setelah permasalahan dan potensi tersebut benar-benar dapat dimanfaatkan, langkah selanjutnya adalah persiapan pasca pelaksanaan program baik itu diskusi tim (tim dengan dosen pendamping, masyarakat sasaran, 
tokoh masyarakat maupun kepala desa Rompegading). Respon dari pihak-pihak kelompok sasaran sangat baik dan mendukung adanya program, yang diharapkan pula dapat berkembang dan diikuti oleh kelompok warga Desa Rompegading.

Sosialisasi awal dilakukan pada hari Minggu, tanggal 22 Agustus 2021 yang diikuti oleh warga Desa Rompegading khususnya kelompok tani. Respon warga dalam pengenalan awal ini sangat baik mereka mendukung sepenuhnya program ini, hal tersebut diketahui dari kuisioner yang diberikan kepada warga. Kegiatan selanjutannya adalah dengan terjun langsung ke masyarakat sebagai sarana pendekatan pada masyarakat, dikusi persiapan pembuatan rumah budidaya lebah Trigona, mulai dari bersih-bersih lokasi tempat budidaya, pemerataan lokasi budidaya, hingga proses pendirian rumah budidaya lebah Trigona.

Untuk target yang sudah tercapai seperti luaran wajib berupa pembuatan manual/panduan aplikasi teknologi produk PHP2D, video kegiatan yang di upload ke cannel youtube Fakultas Kehutanan Universitas Hasanuddin, dan Publikasi media sosial berupa website Fakultas Kehutanan Universitas Hasanuddin. Sedangkan untuk luaran tambahan berupa, publikasi media massa (beritamaros, simpulrakyat, dan frase), jejaring kemitraan yang terbentuk yang dibuktikan dengan perjanjian kerja sama tertulis antara tim pelaksana dengan mitra yaitu dengan Rumah Lebah Bontocani. Sesuai dengan tujuan program Pengembangan Kampung Lebah Trigona sebagai Upaya Pemberdayaan masyarakat Di Desa Rompegading Kabupaten Maros sudah mencapai 100\%.

Dari capaian keberhasilan program dapat dilihat bahwa adanya perubahan perilaku masyarakat dengan adanya ketertarikan akan budidaya lebah hutan Trigona sp., terjadinya perubahan fisik dengan mengurangi kegiatan berburu lebah hutan, terjalinnya kerjasama yang baik antara mitra dengan tim pelaksana serta sangat berpotensi untuk memperluas kemitraan dengan dengan melakukan kerjasama dengan berbagai pihak, terbentuknya kelompok petani lebah trigona, terjadinya peningkatan kegiatan dan komunikasi antara mitra dengan tim pelaksana dalam keberlanjutan program, adanya rancangan program tindak lanjut pasca PHP2D yaitu pemberdayaan masyarakat dalam hal pengemasan dan pemasaran produk, dan adanya implementasi mata kuliah dalam program budidaya lebah Trigona ini.

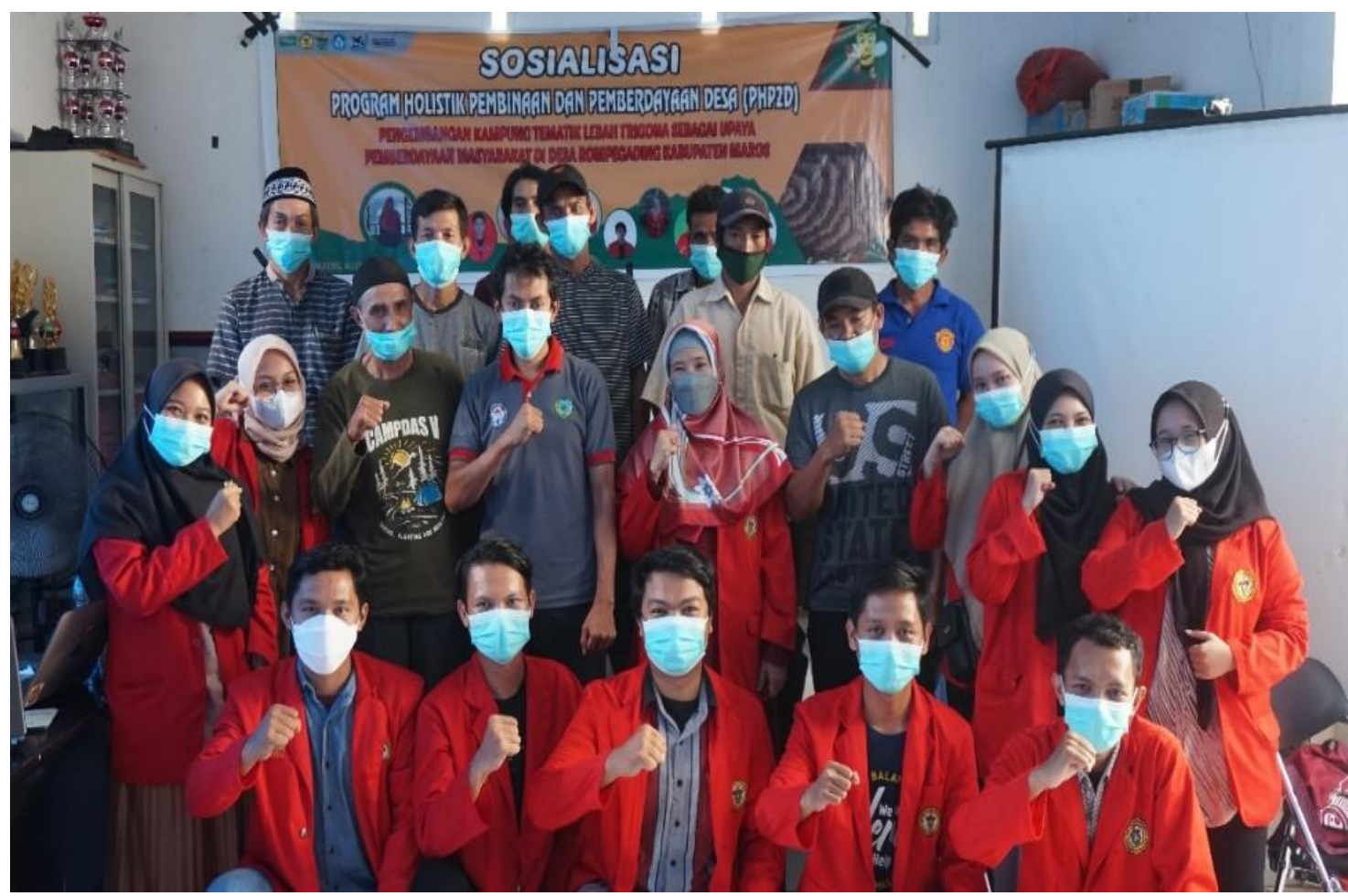

Gambar 2. Sosialisasi program bersama kelompok tani hutan 
Andi Prastiyo, Sitti Nuraeni, Marwan Rajab, Tumanan, Isnul Karima Tullah, Nurfadilah Latif, Nirmala Armidha, Marshabilla, Khairunnisa Salsabillah, Andi Mustainah Rusli, Diky Wahyudi Mitra Mahajana: Jurnal Pengabdian Masyarakat 3(1), 2022, 41-49

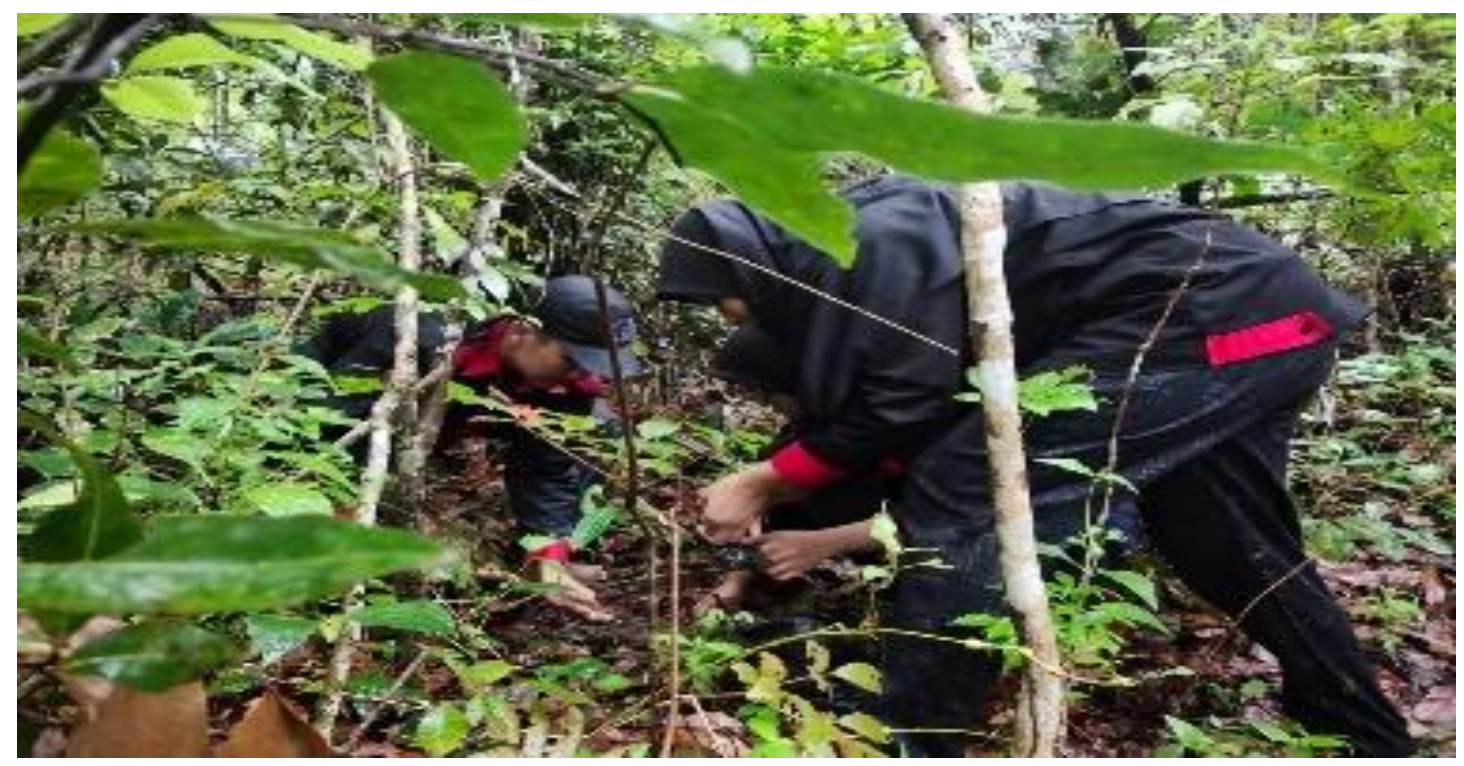

Gambar 3. Penanaman pakan lebah

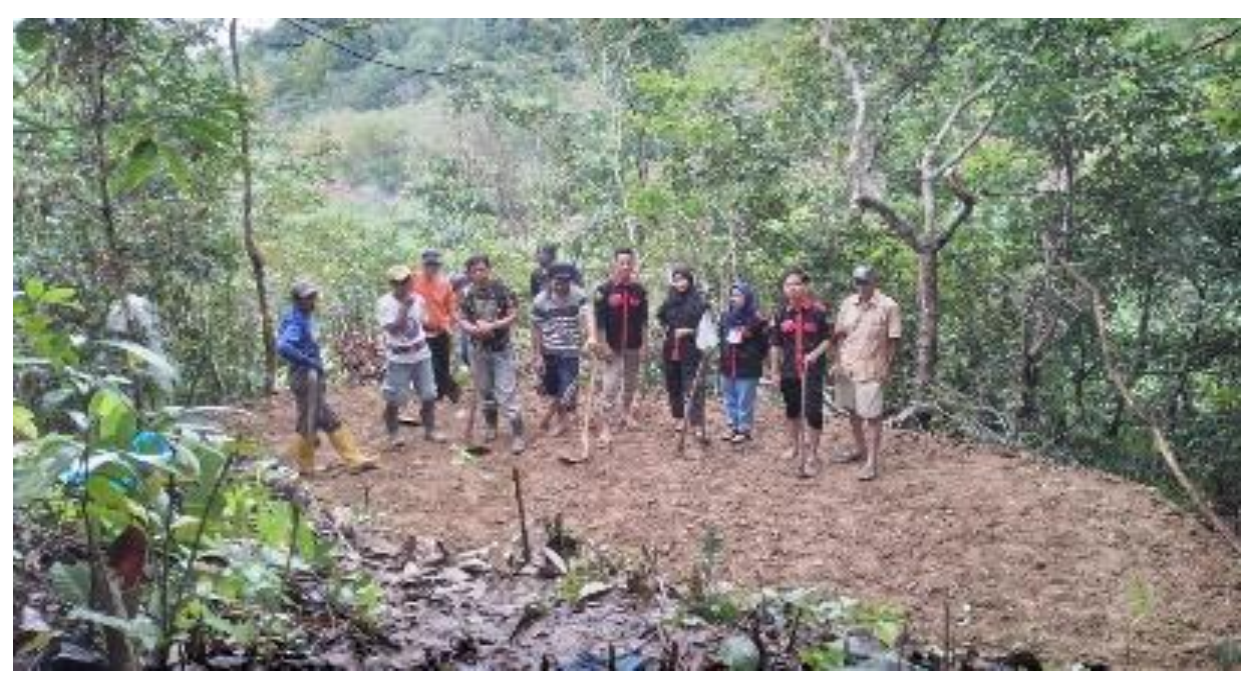

Gambar 4. Penyiapan tempat budidaya lebah

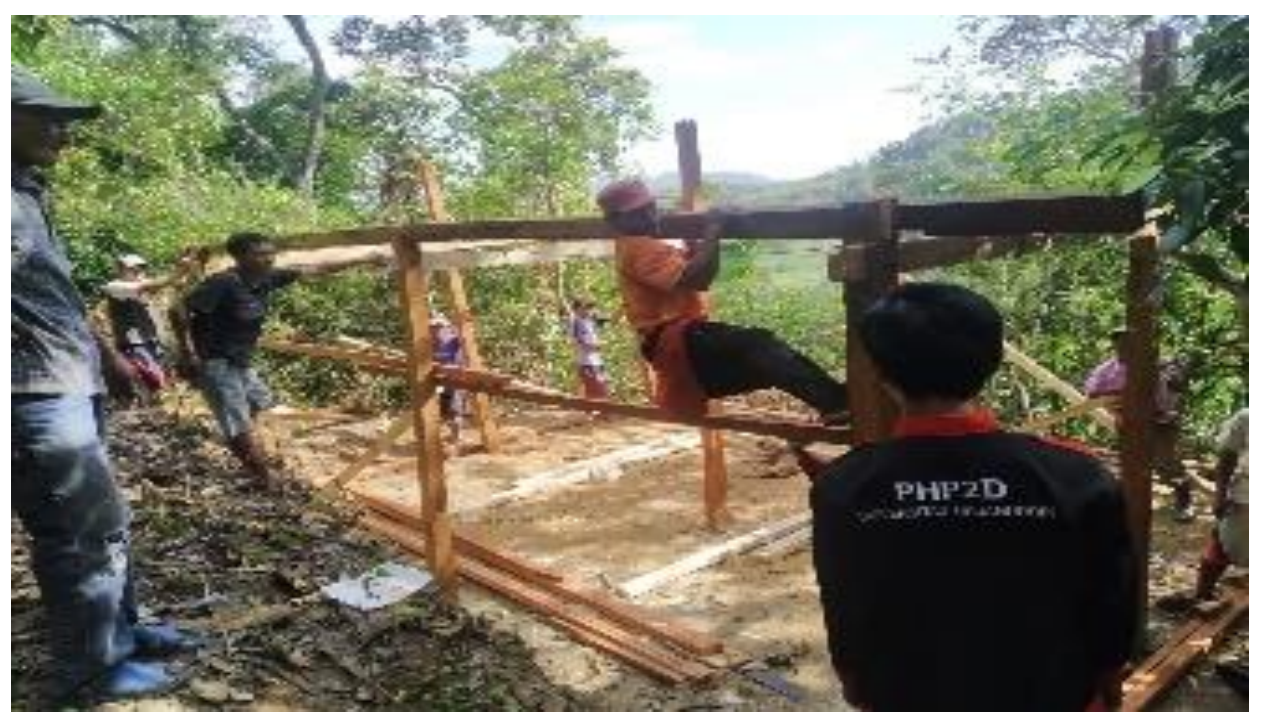

Gambar 5. Pembuatan rumah budidaya lebah 
Andi Prastiyo, Sitti Nuraeni, Marwan Rajab, Tumanan, Isnul Karima Tullah, Nurfadilah Latif, Nirmala Armidha, Marshabilla, Khairunnisa Salsabillah, Andi Mustainah Rusli, Diky Wahyudi Mitra Mahajana: Jurnal Pengabdian Masyarakat 3(1), 2022, 41-49

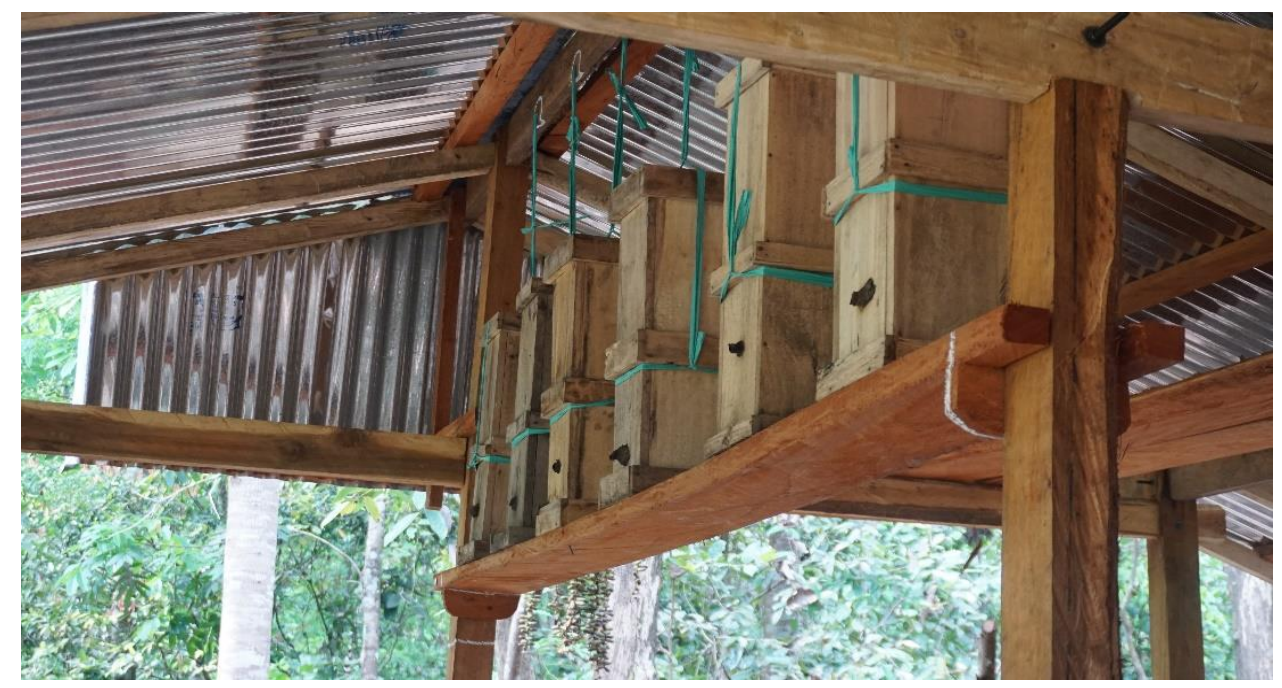

Gambar 6. Rumah Budidaya Lebah

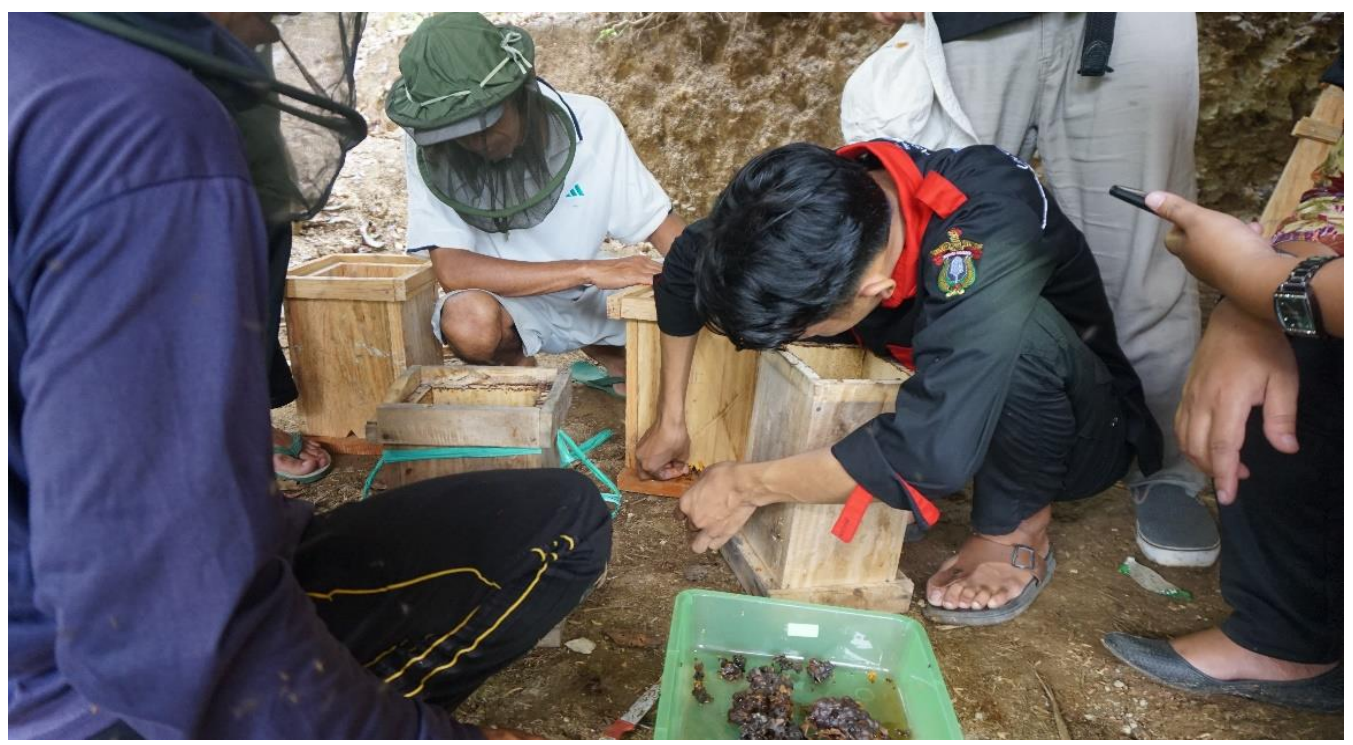

Gambar 7. Pemecahan Koloni Lebah

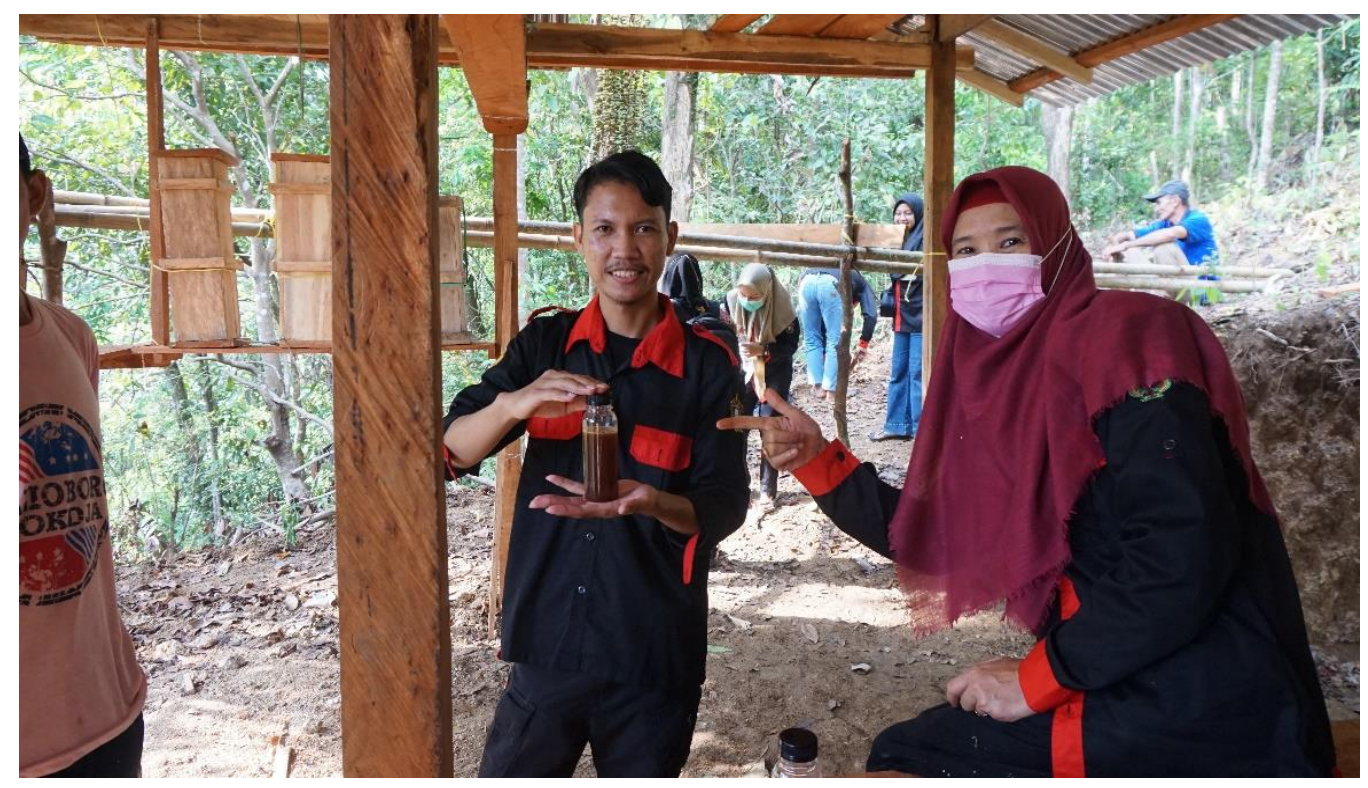

Gambar 8. Hasil Produk

47 | PEMBERDAYAAN MASYARAKAT SEKITAR HUTAN PENDIDIKAN ...MELALUI PENGEMBANGAN MELIPONIKULTUR 
Dari gambar diatas dapat dilihat bahwa budidaya lebah trigona memiliki potensi yang sangat bagus kedepan. Dengan adanya dukungan dan kerjasama mitra, diharapkan dapat menambah pengetahuan masyarakat kelompok tani hutan untuk lebih meningkatkan usaha budidaya lebah trigona. Dengan adanya keberlanjutan program berupa manajemen pengelolaan budidaya, pengemasan dan pemasaran tentunya akan lebih membawa daya tarik terhadap usaha budidaya lebah trigona. Harga pemasaran madu Trigona yang lebih tinggi dibandingkan dengan madu lebah hutan dan mudah dibudidayakan membuat masyarakat mulai tertarik untuk mengembangkannya (Syaifudin \& Normagiat, 2020). Dalam segi kesehatan kandungan gizi madu Trigona lebih baik dibandingkan dengan madu lainnya. Dari hasil penelitian menunjukkan bahwa semakin tinggi tingkat konsentrasi madu lebah Trigona yang ditambahkan, maka semakin besar kemampuan dalam daya hambat serta daya bunuh terhadap pertumbuhan bakteri (Ma'ruf, et al., 2018). Dengan hal itu bahwa budidaya lebah Trigona sangat bermanfaat baik bagi kesehatan bagi yang mengkonsumsi dan bermanfaat untuk menambah perekonomian masyarakat dan secara tidak langsung lebah sebagai polinator sehingga tanaman dapat meregenarasi dengan baik.

Langkah awal yang dilaksanakan dalam program ini meliputi, diskusi/rapat persiapan, survey lapangan, diskusi dengan kelompok sasaran, diskusi dengan tokoh masyarakat dan kepala desa. Dalam pelaksanaan program sendiri yaitu, sosialisasi program, pembentukan kelompok budidaya lebah, penyiapan alat dan bahan, penetapan lokasi budidaya, pengadaan bibit bunga serta pohon, penanaman pakan lebah, penyiapan lokasi budidaya, pembuatan stup, penangkapan koloni lebah di alam, pemecahan koloni, dan pemanenan madu. Terakhir dalam pelaksanaan program yaitu pengemasan produk serta pemasaran produk dan monitoring serta evaluasi pelaksaaan dan keberlanjutan program.

\section{SIMPULAN DAN TINDAK LANJUT}

Tingkat keberhasilan program dapat dikatakan baik sesuai dengan capaian yang akan dilaksanakan dengan memperkenalkan potensi lebah hutan Trigona sp. yang dapat dibudidayakan, memberdayakan petani lebah hutan Desa Rompegading, Kabupaten Maros dengan cara membentuk kelompok tani budidaya lebah Trigona sp. yang berkelanjutan serta mandiri, meningkatkan kapasitas kelompok tani budidaya lebah Trigona sp. di Desa Rompegading dalam budidaya lebah Trigona sp., dan penanganan pasca panen berupa pengemasan dan pemasaran. Saran tindak lanjut berupa pengembangan koloni lebah untuk di perbanyak sehingga hasil yang akan diperoleh nantinya dapat lebih banyak, menghasilkan produk yang sesuai SNI untuk menjamin kualitas produk yang dihasilkan, dan manajemen pemasaran dengan membuat platform sosial yang lebih yang bagus untuk menarik minat konsumen atau pelanggan.

\section{DAFTAR PUSTAKA}

Badan Pusat Statistik Kabupaten Maros. 2018. Kecamatan Cenrana Dalam Angka 2018. Maros: BPS Kabupaten Maros/BPS-Statistic of Maros Regency.

Balai Penelitian dan Pengembangan Teknologi Hasil Hutan Bukan Kayu. 2018. Panduan Singkat Budidaya dan Breeding Lebah Trigona Sp. Mataram: Litbang menlhk.

Dewantari, M dan Suranjaya, I.G. 2019. Pengembangan Budidaya Lebah Madu Trigona Spp Ramah Lingkungan Di Desa Antapan Kecamatan Baturiti Kabupaten Tabanan. Pengabdian Fakultas Peternakan UniversitasUdayana. 18 (1): 114-119.

Jaramaya, R. 2018. Pemerintah akan Canangkan Gerakan Minum Madu. https://www.republika.co.id/berita/nasional/umum/18/09/18/pf8k3s366- pemerintahakan-canangkan-gerakan-minum-madu. Diakses

tanggal 01April 2021.

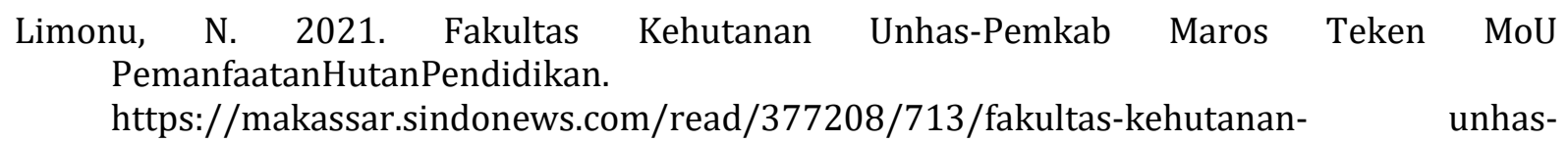


Andi Prastiyo, Sitti Nuraeni, Marwan Rajab, Tumanan, Isnul Karima Tullah, Nurfadilah Latif, Nirmala Armidha, Marshabilla, Khairunnisa Salsabillah, Andi Mustainah Rusli, Diky Wahyudi Mitra Mahajana: Jurnal Pengabdian Masyarakat 3(1), 2022, 41-49

pemkab-maros-teken-mou-pemanfaatan-hutan-pendidikan- $\quad$ 1616745818. Diakses tanggal 02 April 2021.

Ma'ruf, M. et al. 2018. Madu Lebah Kelulut (Trigona Spp.) dalam Aktifitas Terhadap Bakteri Staphylococcus Aureus Resisten. Jurnal Skala Kesehatan Politeknik Kesehatan Banjarmasin. Vol. 9 (1): 1-6.

Moko, H. 2008. Menggalakan Hasil Hutan Bukan Kayu sebagai Produk Unggulan. Informasi teknis Balai Besar Penelitian Bioteknologi dan Pemuliaan Tanaman Hutan. Vol. 6 (2): 1-5.

Mursito. 2011. 70\% Kebutuhan madu RI dipasok produk impor. https://ekonomi.bisnis.com/read/20110712/99/41044/70-percent-kebutuhan- madu-ridipasok-produk-impor. Diakses tanggal 01April 2021.

Syaifudin, S. M. dan Normagiat, S. 2020. Budidaya Pakan Lebah Trigona sp. dengan Apiculture Agroforestry System di Kelurahan Anjungan Melancar Kabupaten Mempawah. Jurnal Ilmiah Pengabdhi. Vol. 6 (1): 18-24.

Yuni, R. Hastuti, P. Afriadi, R. dan Silaban, P.R. 2018. Pengembangan Usaha Ternak Lebah Madu Hutan Nagari Sungai Buluh Nagari Sungai Buluh Timur Kecamatan Batang Anai Kabupaten Padang Pariaman. Jurnal Pengabdian kepada Masyarakat. 24 (4): 890-893. 